\title{
Extensive AL Amyloidosis Presenting with Recurrent Liver Hemorrhage and Hemoperitoneum: Case Report and Literature Review
}

\section{Recidivující krvácení z jater a hemoperitoneum jako následek masivního postižení AL amyloidózou: popis případu a přehled literatury}

\author{
Szturz P. ${ }^{1}$, Kyclova J. ${ }^{2}$, Moulis M. ${ }^{2}$, Navratil M. ${ }^{1}$, Adam Z. ${ }^{,}$Vanicek J. ${ }^{3,4}$, Mayer J. ${ }^{1}$ \\ ' Department of Internal Medicine, Hematology and Oncology, University Hospital Brno and Masaryk University, School of Medicine, Czech Republic \\ ${ }^{2}$ Institute of Pathology, University Hospital Brno and Masaryk University, School of Medicine, Czech Republic \\ ${ }^{3}$ Department of Imaging Methods, Masaryk University, School of Medicine, Czech Republic \\ ${ }^{4}$ International Clinical Research Center - Department of Imaging Methods, St. Anne's University Hospital Brno, Czech Republic
}

\begin{abstract}
Summary
Background: Spontaneous hepatic bleeding is a rare but potentially life-threatening complication of primary systemic amyloidosis. Although the liver is a common site of amyloid deposition, clinical presentation is usually mild or absent. Case: We report a case of a female patient, who had been repeatedly surgically revised because of liver rupture and hemoperitoneum. Initially, the computed tomography finding was interpreted as liver hemangioma. However, based on liver biopsy, the diagnosis had to be changed to primary systemic amyloidosis, and the patient was referred to our hematooncology department. Due to a considerably advanced disease, the patient was eligible only for palliative chemotherapy with cyclophosphamide and dexamethasone, which could not deflect the course of rapidly progressing liver destruction. Conclusion: The cause behind ruptured and bleeding liver does not always need to be hemangioma but rather amyloidosis. In cases of advanced disease and in patients with contraindications for aggressive treatment, the outlook for complete hematological and organ treatment response is very limited. An early diagnosis is of utmost importance. Although liver biopsy brings the definite results, screening for monoclonal protein in serum or urine, leading to a search for AL amyloidosis, may be sufficient for diagnosis. The presence of some of the warning signs (B-symptoms such as fevers or subfebrile temperatures, fatigue, weight loss; and paraneoplastic laboratory findings such as elevated C-reactive protein and erythrocyte sedimentation rate) should raise suspicion of a lymphoproliferative disease.
\end{abstract}

Key words

amyloidosis - hemoperitoneum - hemangiosarcoma - computed tomography - B-symptoms
This publication was prepared as part of the MUNI/A/0723/2012 project as well as it is a part of activities within the European Regional Development Fund-Project FNUSA-ICRC (No.CZ.1.05/1.1.00/02.0123).

Tato publikace byla připravena $v$ rámci aktivity následujících grantů: MUNI/A/0723/2012 a FNUSA-ICRC (No.CZ.1.05/1.1.00/02.0123),

The authors declare they have no potential conflicts of interest concerning drugs, products, or services used in the study.

Autoři deklarují, že $v$ souvislosti s předmětem studie nemají žádné komerční zájmy.

The Editorial Board declares that the manuscript met the ICMJE "uniform requirements" for biomedical papers.

Redakční rada potvrzuje, že rukopis práce splnil ICMJE kritéria pro publikace zasílané do biomedicínských časopisů.

Petr Szturz, MD, Ph.D

Department of Internal Medicine, Hematology and Oncology University Hospital Brno Jihlavska 20

62500 Brno

Czech Republic

e-mail: petr.szturz@fnbrno.cz 


\begin{abstract}
Souhrn
Východiska: Spontánní jaterní krvácení je vzácnou, ale potenciálně život ohrožující komplikací primární systémové amyloidózy. Klinické projevy postižení jaterního parenchymu, který bývá častou lokalizací amyloidových depozit, jsou totiž obvykle mírné nebo nejsou vůbec vyjádřeny. Př́pad: Tato kazuistika popisuje prípad ženy, která podstoupila opakované chirurgické revize pro jaterní rupturu a hemoperitoneum. Vstupně byl nález na vyšetření výpočetní tomografii interpretován jako jaterní hemangiom. Na základě výsledků jaterní biopsie však musela být diagnóza změněna na primární systémovou amyloidózu a pacientka byla odeslána na naši hematoonkologickou kliniku. S ohledem na značně pokročilé onemocnění bylo u pacientky možné pouze podání paliativní chemoterapie s cyklofosfamidem a dexametazonem, která nebyla s to odvrátit nepříznivý průběh rychle progredující destrukce jater. Závěr: Přícinou prasklých a krvácejících jater tedy nemusí být vždy jen hemangiom, ale může se jednat mimo jiné o prípad amyloidózy. V př́padě pokročilého onemocnění a u pacientů s kontraindikacemi pro agresivní léčbu jsou vyhlídky úplné hematologické a orgánové léčebné odpovědi výrazně omezeny. Zcela zásadní je význam včasného stanovení diagnózy. Ačkoli biopsie jater přináší rozhodující výsledky, pro diagnózu může být dostačující screening na přítomnost monoklonálního imunoglobulinu v séru či moči vedoucí k pátrání po př́tomnosti AL amyloidózy. Př́tomnost některých varovných známek (B-příznaky jako horečky nebo subfebrilie, patologická únava, úbytek hmotnosti a paraneoplastické laboratorní nálezy jako zvýšená hladina C-reaktivního proteinu a sedimentace erytrocytů) by měla vyvolat podezření na lymfoproliferativní chorobu.
\end{abstract}

\title{
Klíčová slova
}

amyloidóza - hemoperitoneum - hemangiosarkom - výpočetní tomografie - B-př́iznaky

\section{Introduction}

Primary systemic (immunoglobulin light chain, $\mathrm{AL}$ ) amyloidosis belongs to a group of protein misfolding disorders characterized by deposition of insoluble fibrils in the extracellular matrix [1]. Other forms of systemic amyloidosis include reactive, $\beta 2$-microglobulin and hereditary such as transthyretin, fibrinogen or lysozyme amyloidoses [2-4]. In patients with AL variant, the amyloidogenic protein is derived from monoclonal light chains. Although the liver is a common site of amyloid deposition, clinically significant deteriorations of hepatic functions are rare and reports on spontaneous liver bleeding are exceptional [4].

Herein we report on the case of a woman diagnosed with an aggressive form of primary systemic amyloidosis with predominant liver involvement. Initially, the CT finding was interpreted as atypical liver hemangioma and the patient was repeatedly surgically revised because of liver rupture and hemoperitoneum.

\section{Case Report}

In 2008, a 58-year-old woman presented with dyspeptic symptoms, fatigue and subfebrile temperatures. Her past medical history included arterial hypertension, chronic antral gastritis, large intestine diverticulosis, cholecystectomy and intervertebral disc surgery. Laboratory tests showed gamma-glutamyltransferase $(G G T=261.6 \mathrm{U} / \mathrm{L}$, upper limit for $\mathrm{GGT}=36 \mathrm{U} / \mathrm{L}$ ) and erythrocyte sedimentation rate $(22 \mathrm{~mm} / \mathrm{h}$ and $49 \mathrm{~mm} / 2 \mathrm{~h})$ elevations. Magnetic resonance imaging and computed tomography (CT) of the abdomen displayed only a mild lymphadenopathy near the truncus coeliacus without any explanatory results.

In April 2009 however, a restaging CT examination revealed a large oval

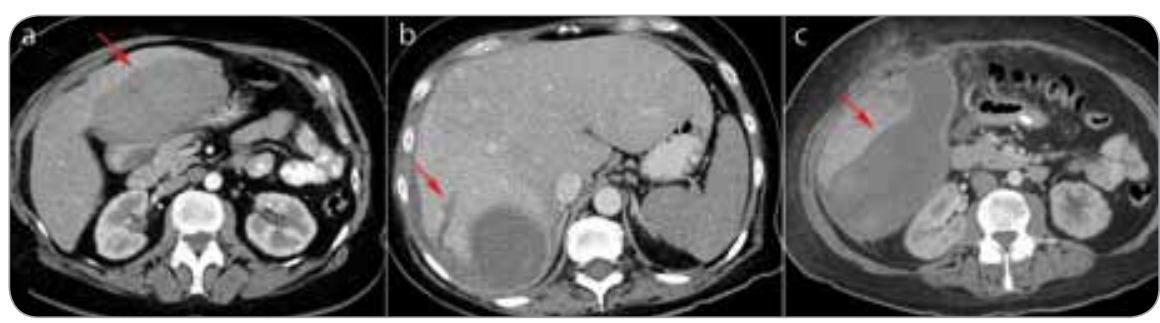

Fig. 1. CT imaging of the affected liver. a) subcapsular infiltration in the left lobe interpreted as atypical hemangioma of the liver (April 2009); b) right liver lobe laceration with a surrounding hematoma causing life-threatening intraabdominal bleeding (August 2009); c) chronic subhepatal hematoma as a residuum after hemoperitoneum (August 2009).

hemangioma-like infiltrate, $10 \times 6 \mathrm{~cm}$ in size, in the left liver lobe. A cytological evaluation of liver aspirate was roughly compatible with the radiologically suspected diagnosis of hemangioma. The patient was then indicated for superselective embolization of the left hepatic artery branch supplying the infiltration expanding rapidly as seen on a series of ultrasound examinations. By that time, GGT further increased to $580.8 \mathrm{U} / \mathrm{L}$, full blood count and coagulation parameters were within normal ranges. In one month after the procedure, the patient was acutely admitted to hospital and repeatedly surgically revised because of hemoperitoneum. The source of the bleeding was apparent on a CT exam as a $10 \mathrm{~cm}$ long laceration of the right liver lobe (Fig. 1). Following the surgical stabilization, gradual liquefaction and regression of the residual subhepatal hematoma were described on a series of ultrasound and $\mathrm{CT}$ investigations.

Nevertheless, the patient's health status worsened and she was repeatedly hospitalized due to recurrent fevers, abdominal pains and weight loss of up to $20 \mathrm{~kg}$ in 6 months. Markedly elevated GGT (1354.2 U/L) and alkaline phosphatase $(A L P=2008.2 \mathrm{U} / \mathrm{L}$, upper limit for ALP = 104.4 U/L) contrasted with normal transaminase and bilirubin levels. Increased C-reactive protein $(C R P=158.2 \mathrm{mg} / \mathrm{L}$, upper limit for $\mathrm{CRP}=5 \mathrm{mg} / \mathrm{L}$ ) was evident. Magnetic resonance cholangiopancreatography 
didn't find any biliary obstruction in the enlarged liver. Clinically rock hard liver with its lower border extending $10 \mathrm{~cm}$ below the costal margin was described and a CT scan showed diffuse inhomogeneous liver parenchyma with multiple new infiltrations.

Then, at a surgical clinic, the woman was indicated for a liver biopsy revealing lambda-AL amyloidosis and finally referred to our hematooncology department. In addition to monoclonal immunoglobulin $\mathrm{G}$ lambda spike $(9.2 \mathrm{~g} / \mathrm{L})$, serum free kappa and lambda light chains were $27.3 \mathrm{mg} / \mathrm{L}$ (upper limit = $19.4 \mathrm{mg} / \mathrm{L}$ ) and $113 \mathrm{mg} / \mathrm{L}$ (upper limit $=26.3 \mathrm{mg} / \mathrm{L}$ ), respectively. Echocardiography identified amyloid heart disease and proteinuria signaling nephropathy was observed (2.75 g per 24 hours, including urine paraprotein). Renal ultrasound did not notice any pathological changes, no electrocardiographic abnormalities were described either. Due to the overall condition of the patient and advanced state of the disease with progressive hepatomegaly and formation of new subcapsular and intraparenchymal hematomas (maximum $16 \times 6 \mathrm{~cm}$ in size), aggressive chemotherapy and liver or hematopoietic stem cell transplantations were contraindicated. The patient was started on low-intensity palliative chemotherapy with cyclophosphamide and dexamethasone.

The aggressivity of the disease was expressed by hypoalbuminemia $(A L B=25 \mathrm{~g} / \mathrm{L}$, lower limit for $A L B=34 \mathrm{~g} / L)$, elevations of $\beta 2$-microglobulin $(\beta 2-\mathrm{m}=6.46 \mathrm{mg} / \mathrm{L}$, upper level for $\beta 2-\mathrm{m}=2.4 \mathrm{mg} / \mathrm{L}$ ) and lactate dehydrogenase ( $L D=808.8 \mathrm{U} / \mathrm{L}$, upper limit for $\mathrm{LD}=213 \mathrm{U} / \mathrm{L}$ ) with physiological serum creatinine concentration and absence of hemolysis. The cholesterol level was increased $(\mathrm{CH}=294 \mathrm{mg} / \mathrm{dL}$, upper level for $\mathrm{CH}=193 \mathrm{mg} / \mathrm{dL}$ ). Two more episodes of hemoperitoneum had occurred in this patient (June 2010 and October 2010) and the woman died of multiorgan failure in November 2010. Autopsy showed $\mathrm{AL}$ amyloidosis with massive infiltration of the liver (weight 3,820 g), myocardium, spleen (sago spleen), kidneys, intraabdominal lymph nodes and suprarenal glands. Microscopic amyloid depositions were found in the bone marrow, lung interstitium, gastric mucosa, tongue and thyroid gland. The liver was extremely fragile and disintegrating at a touch (Fig. 2).

\section{Discussion}

$\mathrm{AL}$ amyloidosis is a clonal disorder of plasma cells producing monoclonal light chains with a potential to aggregate and deposit in bundles of insoluble ß-sheet fibrillar protein [1]. Small populations of pathological plasma cells are found in the bone marrow and/or in the spleen. The diversity of clinical manifestations is related to continuous amyloid protein depositions in a wide variety of tissues leading to multisystem organ dysfunction. Clonal immunoglobulin variable region genes play a particular role in the organ tropism [5]. Most commonly involved are the kidney, heart, nervous system and gastrointestinal tract [6].

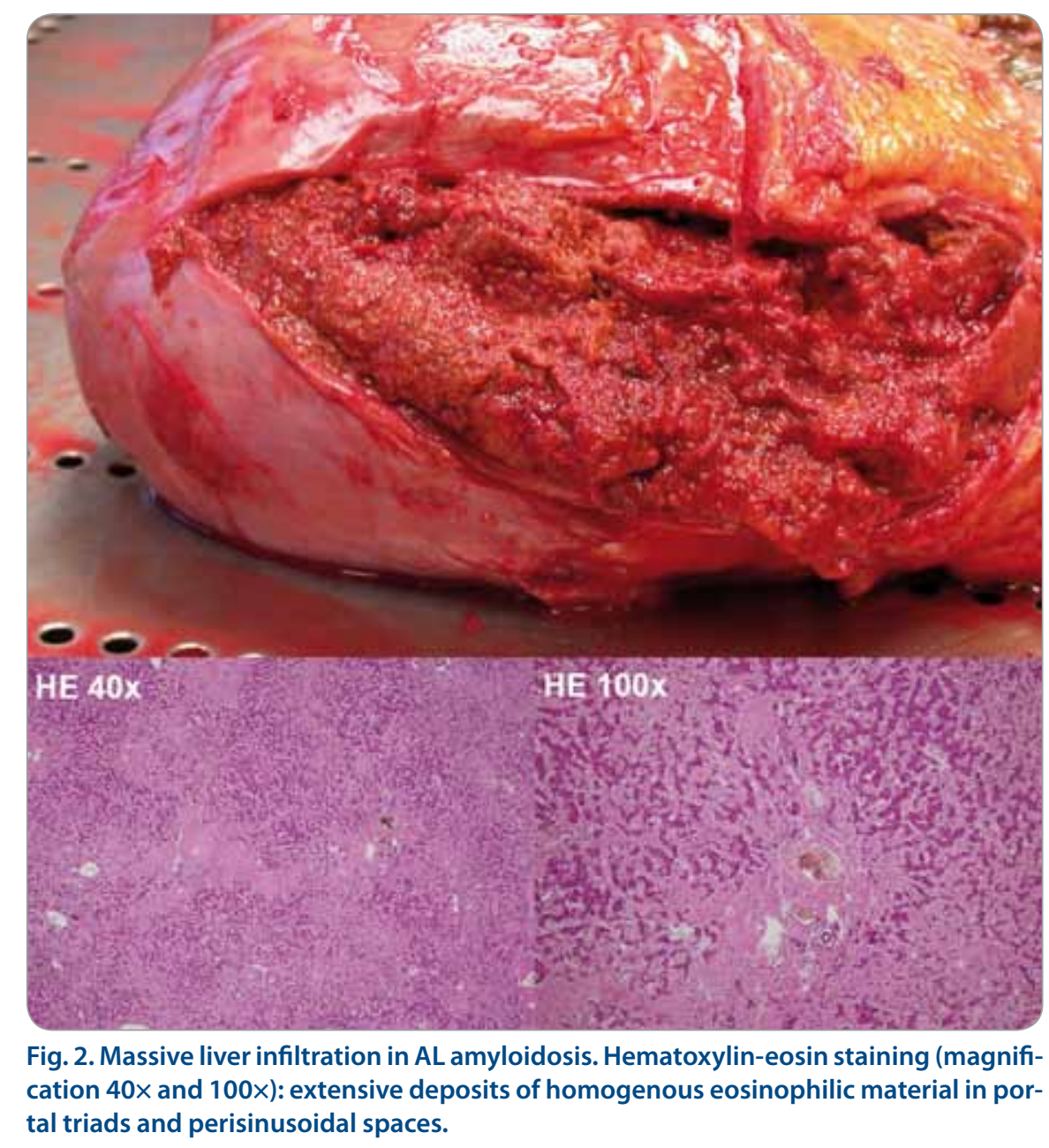

Fig. 2. Massive liver infiltration in AL amyloidosis. Hematoxylin-eosin staining (magnification $40 \times$ and $100 \times$ ): extensive deposits of homogenous eosinophilic material in portal triads and perisinusoidal spaces.
Although liver affection represents a common histological finding and hepatomegaly occurs in about $80 \%$ of the cases, clinical presentation is usually mild or absent. Laboratory tests typically reveal proteinuria, hypercholesterolemia and ALP elevation. In addition, higher ALP levels and CRP levels were shown to indicate liver involvement in patients with AL amyloidosis. Other biochemical liver test abnormalities are inconsistent and tend to appear in the advanced disease $[4,7]$. The following clues were found to indicate the presence of hepatic amyloidosis: (1) proteinuria, (2) serum monoclonal protein with hepatomegaly and/or ALP elevation, (3) Howell-Jolly bodies in the peripheral blood smear $[8,9]$.

Rare complications of hepatic amyloidosis include cholestatic jaundice, ascites, hepatorenal syndrome, portal hypertension or even hepatic failure $[4,7,10]$. Descriptions of spontaneous hepatic 
rupture due to amyloid deposition are mostly limited to single cases [3,11-23] or small series reports $[2,24]$. Although being almost always fatal, successful surgical interventions [17,24], transcatheter hepatic artery embolizations $[16,17]$ and even emergency liver transplantation $[20,21]$ have been reported. Tam et al described a catastrophic course of high-dose melphalan and autologous stem cell transplantation in AL amyloidosis complicated by a spontaneous liver rupture [22]. Not only may patients with AL amyloidosis be affected, but also these with multiple myeloma-associated amyloidosis $[18,23]$, hereditary lysozyme amyloidosis $[2,20,21]$ and hereditary transthyretin amyloidosis [3].

The median survival for patients with primary systemic amyloidosis is about 20 months [9]. Hepatic involvement represents a poor prognostic factor decreasing the median survival to only 9 months [8]. Various treatment options have been proposed including melphalan, prednisone, colchicine, dimethyl sulfoxide, autologous peripheral blood stem cell transplantation following high dose chemotherapy and newly also bortezomib $[25,26]$. The aim of treatment is to eradicate the monoclonal B-cell population leading to cessation of amyloid deposition and its resorption, which in turn may improve organ functions [25]. The median time to organ response is 4 months $[26,27]$. The therapeutic outcome depends on the degree of monoclonal protein reduction, achieving complete remission results in significantly higher portion of improved amyloid-related organ disease [28]. Therefore, while being limited by their toxicity in medically-compromised patients, aggressive modalities represented by stem cell transplantation bring the most promising results.

In our patient, the disease was disclosed in its late-stage, when the liver was irreversibly destructed. Due to the patient's poor performance status and extensive affection of other vital organs, including cardiomyopathy and nephropathy, liver transplantation was contraindicated. The systemic chemotherapy had only a palliative intent. In terms of time, the potential organ treatment response lay beyond the prognostic expectancy of a rapidly progressing oncological disease.

In conclusion, the cause behind ruptured and bleeding liver doesn't always need to be a hemangioma but also amyloidosis may be the case. In cases of advanced disease and in patients with contraindications for aggressive treatment, the outlook for a complete hematological and organ treatment response is very limited. Therefore, an early diagnosis is of utmost importance. Although a liver biopsy brings the definite results, screening for monoclonal protein in serum or urine, leading to a search for $A L$ amyloidosis, may be sufficient for the diagnosis. The presence of some of the warning signs (B-symptoms such as fevers or subfebrile temperatures, fatigue, weight loss; and paraneoplastic laboratory findings such as elevated acute-phase markers) should raise suspicion of a lymphoproliferative disease [29-31].

\section{References}

1. Merlini G, Bellotti V. Molecular mechanisms of amyloidosis. N Engl J Med 2003; 349(6): 583-596.

2. Loss M, Ng WS, Karim RZ et al. Hereditary lysozyme amyloidosis: spontaneous hepatic rupture (15 years apart) in mother and daughter. role of emergency liver transplantation. Liver Transpl 2006; 12(7): 1152-1155.

3. Michowska M, Boj E, Wrzołkowa T et al. A First Case of Liver Rupture In Transthyretin (TTR) Familial Amyloid Polyneuropathy. Exp Clin Hep 2005; 1(2): 109-112

4. Gertz MA, Kyle RA. Hepatic amyloidosis: clinical appraisal in 77 patients. Hepatology 1997; 25(1): 118-121.

5. Comenzo RL, Zhang Y, Martinez C et al. The tropism of organ involvement in primary systemic amyloidosis: contributions of $\lg \mathrm{V}(\mathrm{L})$ germ line gene use and clonal plasma cell burden. Blood 2001; 98(3): 714-720.

6. Solomon A, Macy SD, Wooliver C et al. Splenic plasma cells can serve as a source of amyloidogenic light chains. Blood 2009; 113(7): 1501-1503.

7. Park MA, Mueller PS, Kyle RA et al. Primary (AL) hepatic amyloidosis: clinical features and natural history in $98 \mathrm{pa}-$ tients. Medicine (Baltimore) 2003; 82(5): 291-298.

8. Gertz MA, Kyle RA. Hepatic amyloidosis (primary [AL] immunoglobulin light chain): the natural history in $80 \mathrm{pa}-$ tients. Am J Med 1988; 85(1): 73-80.

9. Gertz MA, Kyle RA. Primary systemic amyloidosis - a diagnostic primer. Mayo Clin Proc 1989; 64(12): 1505-1519. 10. Peters RA, Koukoulis G, Gimson A et al. Primary amyloidosis and severe intrahepatic cholestatic jaundice. Gut 1994; 35(9): 1322-1325.

11. Ades CJ, Strutton GM, Walker NI et al. Spontaneous rupture of the liver associated with amyloidosis. J Clin Gastroenterol 1989; 11(1): 85-87.

12. Hurd WW, Katholi RE. Acquired functional asplenia. Association with spontaneous rupture of the spleen and fatal spontaneous rupture of the liver in amyloidosis. Arch Intern Med 1980; 140(6): 844-845.

13. Bujanda L, Beguiristain A, Alberdi F et al. Spontaneous rupture of the liver in amyloidosis. Am J Gastroenterol 1997; 92(8): 1385-1386.

14. Ooi LL, Lynch SV, Graham DA et al. Spontaneous liver rupture in amyloidosis. Surgery 1996; 120(1): 117-119.

15. Satue JA, Ortuño T, Carabias E et al. Fatal spontaneous liver rupture in a renal transplant patient with amyloidosis. Nephron 1996; 73(2): 355-356.

16. Mosconi G, Scolari MP, Feliciangeli G et al. Combined liver-kidney transplantation with preformed anti-HLA antibodies: a case report. Transplant Proc 2006; 38(4): 1125-1126.

17. Kacem C, Helali K, Puisieux F. Recurrent spontaneous hepatic rupture in primary hepatic amyloidosis. Ann Intern Med 1998; 129(4): 339.

18. Mukhopadhya A, Raghuram L, Justus A et al. Transcatheter hepatic artery embolization for spontaneous rupture of amyloid liver. Indian J Gastroenterol 2004; 23(1): 26-27.

19. Naito KS, Ichiyama T, Kawakami S et al. AL amyloidosis with spontaneous hepatic rupture: successful treatment by transcatheter hepatic artery embolization. Amyloid 2008; 15(2): 137-139.

20. Harrison RF, Hawkins PN, Roche WR et al. Fragile' liver and massive hepatic haemorrhage due to hereditary amyloidosis. Gut 1996; 38(1): 151-152.

21. Mells GF, Buckels JA, Thorburn D. Emergency liver transplantation for hereditary lysozyme amyloidosis. Liver Transpl 2006; 12(12): 1908-1909.

22. Tam M, Seldin DC, Forbes BM et al. Spontaneous rupture of the liver in a patient with systemic AL amyloidosis undergoing treatment with high-dose melphalan and autologous stem cell transplantation: a case report with literature review. Amyloid 2009; 16(2): 103-107.

23. Okazaki K, Moriyasu F, Shiomura T et al. Spontaneous rupture of the spleen and liver in amyloidosis - a case report and review of the literature. Gastroenterol Jpn 1986; 21(5): 518-524.

24. Gastineau DA, Gertz MA, Rosen CB et al. Computed tomography for diagnosis of hepatic rupture in primary systemic amyloidosis. Am J Hematol 1991; 37(3): 194-196. 25. Kumar KS, Lefkowitch J, Russo MW et al. Successful sequential liver and stem cell transplantation for hepatic failure due to primary AL amyloidosis. Gastroenterology 2002; 122(7): 2026-2031.

26. Kastritis E, Anagnostopoulos A, Roussou M et al. Treatment of light chain ( $\mathrm{AL}$ ) amyloidosis with the combination of bortezomib and dexamethasone. Haematologica 2007; 92(10): 1351-1358

27. Dhodapkar MV, Hussein MA, Rasmussen E et al. Clinical efficacy of high-dose dexamethasone with maintenance dexamethasone/alpha interferon in patients with primary systemic amyloidosis: results of United States Intergroup Trial Southwest Oncology Group (SWOG) S9628. Blood 2004; 104(12): 3520-3526.

28. Skinner M, Sanchorawala V, Seldin DC et al. High-dose melphalan and autologous stem-cell transplantation in patients with AL amyloidosis: an 8-year study. Ann Intern Med 2004; 140(2): 85-93.

29. Sýkorová A, Belada D, Smolej L et al. Určování rozsahu onemocnění u non-Hodgkinových lymfomů - doporučení Kooperativní lymfomové skupiny. Klin Onkol 2010; 23(3): 146-154.

30. Machálková K, Maisnar V. Využití prokalcitoninu v diferenciální diagnostice febrilií u pacientů s mnohočetným myelomem. Klin Onkol 2011; 24(4): 298-301.

31. Ščudla V, Pika T. Současné možnosti diagnostiky a léčby systémové AL-amyloidózy. Vnitř Lék 2009; 55 (Suppl 1): $77-87$ 